\title{
HISTORIOGRAFIA DA REGIÃO DE DOBRAMENTOS DO MÉDIO COREAÚ
}

\author{
JOAQUIM RAUL TORQUATO* \& JOSÉ DE ARAÚJO NOGUEIRA NETO*
}

\begin{abstract}
HISTORIOGRAPHY OF THE MÉDIO COREAÚ FOLD REGION The região de Dobramentos do Médio Coreaú, known since the beginning of the century, is the most spectacular geologic feature of Ceará and may be one of the most important of the northeastern Brazil

According to Brito Neves (1995), it corresponds to an Orogenic Belt, which includes a variety of lithotypes with different ages and origins within one single tectonic unit. This region, together with Maciço de Granja, extends along the whole portion of the extreme northwest of Ceará, and is situated to the north of the Sobral-Pedro II lineament. In this paper we present a summary of the historical stratigraphic concepts of the seven main units described in the region, which comprise:

1) the Jaibaras Group, which represents a molassic unit with volcanic intercalations deposited in a graben and unconformably overlying the Ubajara.Group. A total rock $\mathrm{Rb} / \mathrm{Sr}$ isochron yield and age of $535 \pm 27$ Ma (Novais et al. 1979). This unit probably underwent prehnita-pumpelleyte facies (Jardim de Sá et al 1979).

2) the Ubajaras Group includes pelites-psammites, sandstones, graywackes and limestones (Costa et al. 1973), and is cut by granite with a total rock $\mathrm{Rb} / \mathrm{Sr}$ age of $550 \pm 30 \mathrm{Ma}$ (Sial et al. 1981).

3 ) the Chaval Granite, a sinorogenic and strongly sheared intrusion of total rock Rb/Sr age of $507 \pm 27 \mathrm{Ma}$ (Nogueira Neto et al. 1989).

4) the Martinópole Group, made up of phyllites, schists, limestones, metavulcanics, and mylonitic quartzite, all metamorphosed under green schist facies. $\mathrm{U} / \mathrm{Pb}$ data of zircon of metavolcanic rocks intercalated in the metasedimentary rocks yield a Neoproterozoic age of $808 \pm 7,8$ Ma for the sedimentation (Fetter et al. 1995). 5) the São Joaquim Group, which includes $1.500 \mathrm{~m}$ thick quartzites and many intercalation of ortho and paragneisses (Torquato et al. 1987).

6) the Granja Granulitic Belt, represented by khondalites, charnockitic gneisses, enderbites and mafic granulites. These rocks yield a $\mathrm{Pb} / \mathrm{Pb}$ zircon age of nearly $2.0 \mathrm{Ga}$ (Gaudette et al. 1993), and a U/Pb age of zircon of $2.2 \mathrm{Ga}$ (Fetter et al. 1995).

7) the Granja Complex Ortogneisses of tonalitic-granodioritic composition, which may represent reworked basement rocks. $\mathrm{Pb} / \mathrm{Pb}$ ages of zircon from two gneisses of the vicinities of the city of Granja are of $2.028 \pm 30 \mathrm{Ma}$ and 2.253 $\pm 27 \mathrm{Ma}$ (Gaudette et al. 1993), while $\mathrm{U} / \mathrm{Pb}$ in zircon of the same region yield ages between 2.290 and $2.360 \mathrm{Ma}$ (Fetter et al. 1995)
\end{abstract}

Keywords:

RESUMO Conhecida desde o início do século, a Região de Dobramentos do Médio Coreaú é a mais espetacular feição geológica do Ceará e talvez mesmo uma das mais importantes do Nordeste.

A Região de Dobramentos do Médio Coreaú, conforme definido originalmente por Brito Neves (1975), corresponde a um Cinturão Orogênico (Orogenic Belt), o qual engloba uma variedade de litótipos com distintas idades e origens numa mesma unidade tectônica. Esta região, juntamente com o Maciço de Granja, ocupa toda a porção do extremo noroeste do Ceará, e está situada a norte do lineamento Sobral-Pedro II.

Neste trabalho apresentamos o resumo histórico estratigráfico e evolutivo das sete principais unidades litoestratigráficas descritas para a região:

1) Grupo Jaibaras, que representa uma unidade molássica com intercalações de rochas vulcânicas, posicionado sob a forma de graben, e sobreposta em discordância ao Grupo Ubajara. Uma isócrona $\mathrm{Rb} / \mathrm{Sr}$ em rocha total forneceu a idade de $535 \pm 27$ Ma (Novais et al. 1979). Essa unidade parece ter atingido o fácies prehnita-pumpelleyta (Jardim de Sá et al. 1979);

2) Grupo Ubajara, inclui pelitos-psamitos, arenitos-grauvacas e litótipos calcários (Costa et al. 1973). Este conjunto é coitado por granitos, cuja isócrona $\mathrm{Rb} / \mathrm{Sr}$ em rocha total proveu idade de $550 \pm 30 \mathrm{Ma}$. (Sial et al. 1981);

3) Granito Chaval, sinorogênico fortemente cisalhado, com idade $\mathrm{Rb} / \mathrm{Sr}$ em rocha total de $507 \pm 27 \mathrm{Ma}$ (Nogueira Neto et al. 1989);

4) Grupo Martinópole, constituído por filitos, xistos, carbonates impuros, metavulcânicas e quartzitos milonfticos, todos metamorfisados no facies xisto-verde. Freqüentemente apresentam redobramentos recumbentes de clivagem. Dados U/Pb em zircões, de metavulcânicas intercaladas nos metasedimentos, forneceram idade Neoproterozóica (808 $\pm 7,8$ Ma.) para a sedimentação (Fetter et al. 1995);

5) Grupo São Joaquim, que inclui metaquartzitos (1500 m de espessura) e várias intercalações de oito e paragnaisses (Torquato et al. 1987);

6) Faixa granulítica de Granja, representada por khondalitos, gnaisses charnockiticos, enderbitos e granulitos máficos. Apresentam idades $\mathrm{Pb} / \mathrm{Pb}$ por evaporação de zircões de aproximadamente $2000 \mathrm{Ma}$ (Gaudette et al. 1993), enquanto a idade $\mathrm{U} / \mathrm{Pb}$ em zircões forneceu $2200 \mathrm{Ma}$. (Fetter et al. 1995);

7) Ortognaisses de composição diorftica, tonalítica e granodiorítica os quais podem representar o embasamento pré-brasiliano retrabalhado. Idades $\mathrm{Pb} / \mathrm{Pb}$ por evaporação de zircões deram $2028 \pm 30 \mathrm{Ma}$ e $2253 \pm 27 \mathrm{Ma}$ respectivamente para dois gnaisses nas imediações da cidade de Granja (Gaudette et al. 1993). Dados U/Pb em zircões de três gnaisses da região forneceram idades entre 2290 e $2360 \mathrm{Ma}$ (Fetter et al. 1995).

Palavras-chaves:

INTRODUÇÃO Conhecida desde o início do século, a Região de Dobramentos do Médio Coreaú é a mais espetacular feição geológica do Ceará e talvez mesmo uma das mais importantes do Nordeste. A sua diversidade quer em litótipos, quer estratigráfica obrigou, em 1926, Williams a escrever: "Em todo o Brasil não conheço outra área egual que enfeixe tantos pontos de alto interesse scientifico e econômico como esta, onde elles sobressahem duma maneira tão exuberante e clara".
Até agora foram feitos mais de duas centenas de artigos, teses e comunicações em congressos e simpósios que abordam, de quase todas as maneiras conhecidas, os diversos aspectos da geologia da região.

A Região de Dobramentos do Médio Coreaú, como definido originalmente por Brito Neves (1975), corresponde a um Cinturão Orogênico (Orogenic Belt), o qual engloba uma variada gama de litótipos com distintas idades e origens numa mesma unidade tectônica (Figura 1). Esta região, juntamente 
com o Maciço de Granja, ocupa toda a porção do extremo noroeste do Ceará, e está situada a norte do lineamento Sobral-Pedro II.

A maioria dos trabalhos que tratam da geologia do canto noroeste do Ceará indica Crandall (1910) como o primeiro autor a descreve-la. Puro engano! Crandall nunca escreveu nada sobre a região nem nunca esteve por lá. $\mathrm{Na}$ Introdução ao seu trabalho, ao indicar o seu itinerário, ele mesmo diz " $O$ autor... entrando no Estado da Parahyba perto de Conceição do Piancó e continuou para oeste até Brejo dos Santos, depois para norte por Milagres até Icó. Dahi o caminho faz uma volta para leste em direcção da Parahyba ... e daquelle ponto, voltando em rumo noroeste, para Baturité por Batalhão ... Limoeiro e Russas".

$\dot{E}$ evidente que Crandall (1910) quando subdividiu o Ceará nos dois grandes conjuntos de rochas "Série Ceará" e "Complexo Fundamental", mesmo sem querer, dividiu estratigraficamente o noroeste do Ceará, deste modo, e só com esta visão, se pode admitir o seu pioneirismo.

É muito mais antiga, mas sem continuidade de trabalhos, a primeira citação de cunho geológico de que temos conhecimento. O Barão de Eschwege, no seu famoso livro "Pluto Brasiliensis", publicado na Alemanha em 1833, já indica a ocorrência de cobre na mina de Pedra Verde.

A sua evolução quer estratigráfica quer estrutural começou, não se sabe exatamente quando, mas, provavelmente que durante os primórdios do Proterozóico Médio já existiam alguns dos seus constituintes. Os gnaisses e migmatitos que formam o embasamento onde as diferentes unidades estratigráficas assentam, já tem idades da ordem dos 2200 a 2300 milhões de anos. Os quartzitos do Grupo São Joaquim também devem pertencer à mesma idade. As primeiras datações próprias do Cinturão orogênico fornecem-nos idades $\mathrm{U} / \mathrm{Pb}$ de 808 土 7,8 Ma para a sedimentação dos litótipos Martinópole.

A evolução regional sofreu fortes pulsos de sedimentação e tectônicos durante toda a sua evolução. Os últimos eventos de porte que ali ocorreram, o magmatismo físsural de idade mesozóica, pouco mudou os aspectos físiográficos locais embora, até hoje, se continuem a processar por toda a área fenômenos de basculamento e distensão regional (Saadi \& Torquato, 1992).

RESUMO ESTRATIGRÁFICO DA REGIÃO O presente resumo estratigráfico da região foi baseado fundamentalmente em Torquato (1995).

Grupo Jaibaras A Small (1914) se deve a primeira descrição das rochas que hoje fazem parte do Grupo Jaibaras, contudo, só em 1943, Oliveira \& Leonardos passam a chamálas de "Série Jaibara" (no singular). Kegel (1956) faz a primeira divisão estratigráfica destas rochas, e reconhece a presença de um conglomerado basal, arenitos e folhelhos intermediários e o "calcário Bambui" capeando a sucessão. Kegel et al. (1958) passam o nome para Formação Jaibara subdividida em dois Membros, Trapiá e Aprazível. Cobra (1963) voltou com o termo "Serie Jaibaras" (agora no plural) e admitiu nela a presença de um ciclo vulcânico intermediário, organizou todas as outras litologias em função da idade do vulcanismo (Tabela I). Costa (1963) inverte as nomenclaturas estratigráficas de Kegel et al (1958), passa os membros para a categoria de formações e subdivide a Trapiá em dois novos membros. Winge (1967) denomina o conjunto como "Grupo Jaibaras", subdividido em vários subgrupos. A grande mudança na estratigrafia da região deve-se a Costa et al. (1973) que subdividiram o Grupo Jaibaras nas quatro formações que ainda hoje são usadas por muitos autores: Aprazível com arenitos e arenitos conglomeráticos polimíticos, Parapui formada por rochas estrusivas e intrusivas físsurais ácidas e básicas, Pacujá onde predominam os arenitos líticos, folhelhos e siltitos e Massapê com os seus belos conglomerados brechóides. Em 1979, Jardim de Sá e colaboradores propõem uma nova divisão (que nunca mais foi usada) para a região, com cinco formações em vez das quatro já existentes, e simplesmente com nomes colocados alfabeticamente de A a E. Nascimento \& Gava (1979) retiram do conjunto de Costa et al (1973) a formação vulcânica -Parapui - e usam o restante tal como aqueles autores. Prado et al (1981) recolocam a Formação Parapui no seu lugar anterior estendendo a sua idade para o Cambro-Ordoviciano e, finalmente, Goraieb ei ai (1988) criam uma nova

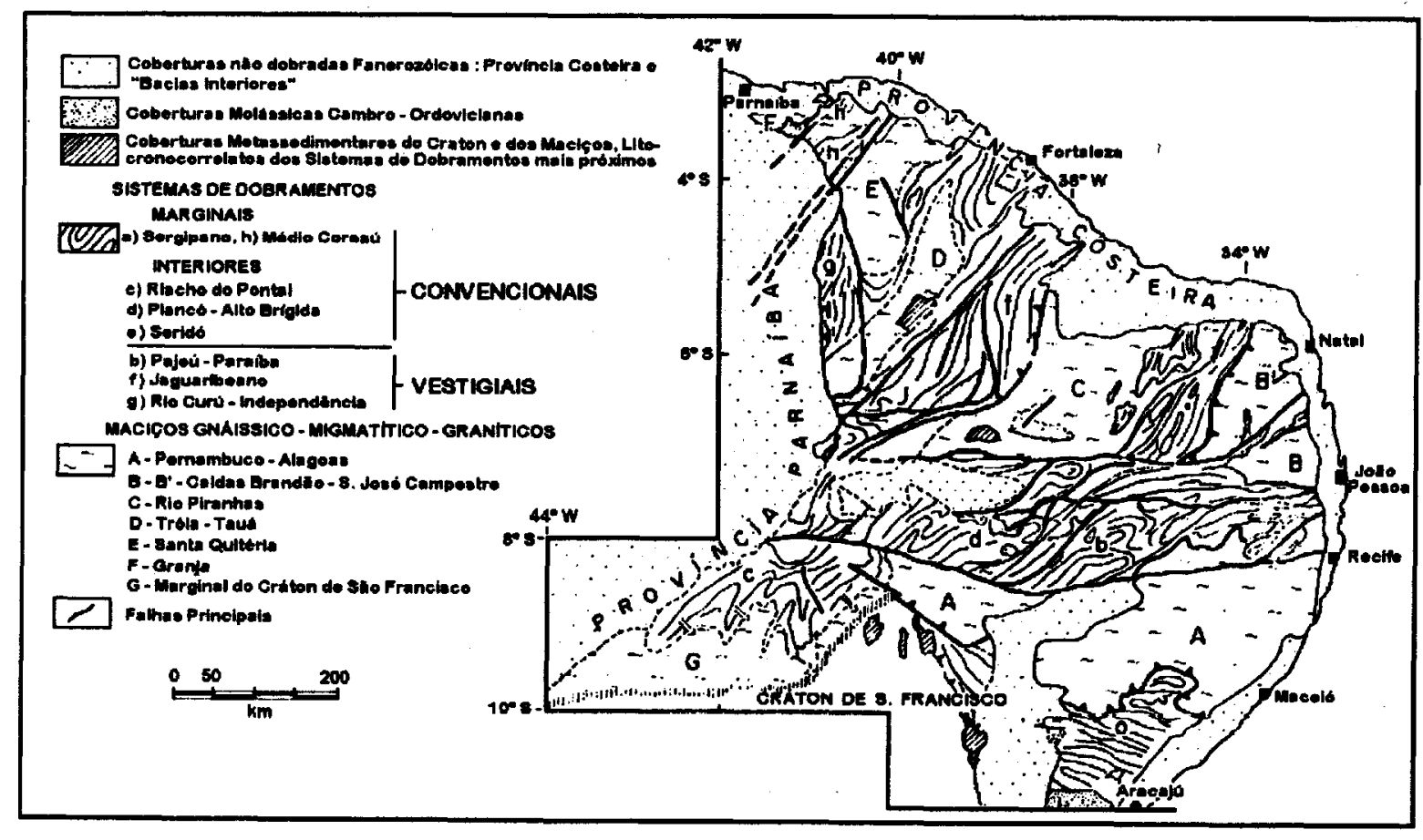

Figura 1 - Esboço dos elementos geológicos principais da Província Borborema (Brito Neves 1983) Figure l - Sketch of the main geologic elements of the Borborema Province (Brito Neves 1983) 
Tabela 1 - Quadro comparativo das colunas estratigráficas propostas para o Grupo Jaibaras

Table 1 - Comparisons of the several stratigraphic proposals for the Jaibaras Group

\begin{tabular}{|c|c|c|c|}
\hline \multirow{2}{*}{$\begin{array}{ll} & \text { Idade } \\
\text { Autor (ano) } & \\
\end{array}$} & \multicolumn{3}{|c|}{ PALEOZÓICO } \\
\hline & Siluriano & Ordoviciano & Cambriano \\
\hline Oliveira \& Leonardos (1943) & Sério Jaibara & & \\
\hline Kegel (1956) & Calchrio Bambul & $\begin{array}{r}\text { Série Jaibara } \\
\text { Arenitos e folhelhos ve }\end{array}$ & redos \\
\hline Kegel et al... (1958) & & 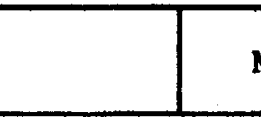 & $\begin{array}{l}\text { Jaibara } \\
\text { rapiá } \\
\text { ro Aprazível }\end{array}$ \\
\hline Cobra (1963) & Siltito/Arenito Pó & $\begin{array}{l}\text { Sórie Jaibaras } \\
\text { lcânico } \\
\text { nglomerados } \\
\text { Rochas vulcânica } \\
\text { Siltito }\end{array}$ & nico \\
\hline Costa (1963) & & 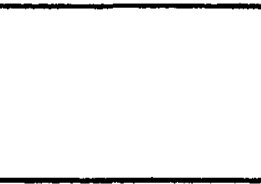 & $\begin{array}{l}\text { Série Jaibara } \\
\text { Fm. Aprazivel } \\
\text { Intrusరes e derrames } \\
\text { Fm Trapid| Memb. Superior } \\
\text { | Memb. Inforior } \\
\end{array}$ \\
\hline Winge (1967) & & 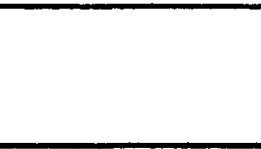 & $\begin{array}{l}\text { Grupo Jaibaras } \\
\text { Sub-Grupo Superior } \\
\text { Sub-Grupo Medio } \\
\text { Sub-Grupo Basal }\end{array}$ \\
\hline $\begin{array}{l}\text { Mabescone et al. } \\
\text { (1971) }\end{array}$ & Fm. Aprazivel & $\begin{array}{l}\text { Grupo Jaibare } \\
1 \\
\end{array}$ & $\begin{array}{l}\text { atrusives } \\
\text { Fm. Trapiá }\end{array}$ \\
\hline Danai (1972) & r. & $\begin{array}{l}\text { Grupo Jaibaras } \\
\text { Fm. Aprazdvel } \\
\text { Rochas Ígneas } \\
\text { Fm. Trapiá } \\
\end{array}$ & \\
\hline Costa et al. (1973) & & 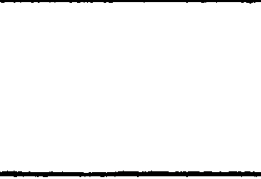 & $\begin{array}{l}\text { O Jaibaras } \\
\text { prezivel } \\
\text { Parapui } \\
\text {. Pacujá } \\
\text { Fm. Massape } \\
\end{array}$ \\
\hline Jardim de Sá et al. (1979) & & $x^{2}$ & $\begin{array}{l}\text { Grupo Jaibaras } \\
\text { Fm. E } \\
\text { Fm. D } \\
\text { Fm. C } \\
\text { Fm. B } \\
\text { Fm. A }\end{array}$ \\
\hline Novais et al. (1979) & & Fm. Aprazi & $\begin{array}{l}\text { Taibaras } \\
\text { arapui } \\
\text { m. Pacujá } \\
\text { Fm. Massape }\end{array}$ \\
\hline Nascimento \& Gava (1979) & & 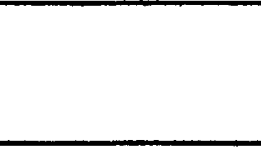 & $\begin{array}{l}\text { Jaibaras } \\
\text { azivel } \\
\text { Pacuja } \\
\text { m. Massape }\end{array}$ \\
\hline Prado et al.. (1981) & & $\begin{array}{r}G \\
\text { Fm. Apr } \\
\text { Fm. } \\
F\end{array}$ & ras \\
\hline Goraieb et al. (1988) & & & $\begin{array}{l}\text { Fm. Aprazivel } \\
\text { Suite Meruoca } \\
\text { Suite Parapui } \\
\text { Grupo Jaibaras } \\
\text { Fm. Massapê } \\
\text { Fm. Pacujá }\end{array}$ \\
\hline
\end{tabular}


nomenclatura para estas rochas, passando a admitir que a Formação Aprazível e Parapui, bem como a Suite Meruoca estão posicionadas sobre as rochas do Grupo Jaibaras que, para eles, é formado exclusivamente pelas rochas Massapê e Pacujá, mas em posição estratigráfica invertida em relação ao até então apresentado. Os presentes autores concordam que não é fácil fazer uma coluna estratigráfica em que se enquadrem, de modo indiscutível, todos os litótipos da região, assim, quer temporalmente, quer estratigraficamente, apoiam e usam as idéias de Prado et al, (1981).

Grupo Ubajara Tal como no grupo anterior, foi Small (1914) quem, pela primeira vez, descreveu as litologias hoje pertencentes ao Grupo Ubajara. Williams (1926) e Oliveira \& Leonardos (1943) citam no local a presçnça de calcários. Kegel (1956) dá-lhes o nome de "Formação Bambuí". Cobra (1963) passa-lhe o nome para "Série" Bambuí, subdividida em filitos e quartzitos na base, calcários intermediários e arenitos finos no topo. Mabesoone (1971) eleva essas rochas à categoria de "Grupo Bambuí" com duas Formações: "Caiçaras" e "Bambuí". Costa et al (1973) apresentam para o grupo a estrutura que ainda hoje a maioria dos autores utiliza, com a subdivisão do grupo em quatro formações: Coreaú onde predominam os arcóseos e grauvacas conglomeráticas, Frecheirinha com os seus famosos calcários, Caiçaras onde as belas ardósias vermelhas e roxas se misturam e Trapiá com arenitos grosseiros e quartzitos conglomeráticos. Nascimento \& Gava (1979), por razões de ordem de nomenclatura estratigráfica, mudam o nome do grupo de Bambuí para Ubajara e suprimem a Formação Coreaú que passa a ser englobada pela Formação Pacujá do Grupo Jaibaras. Cavalcante \& Ferreira (1983) reintegram a Formação Coreaú no mapa geológico do Ceará, a qual é novamente retirada por Goraieb et al (1988) e ali novamente recolocada, no mesmo ano, por Hackspacher (1988) (Tabela II). Os presentes autores admitem, pelo conhecimento que tem da região, que o esquema que melhor se adapta é o de Nascimento \& Gava (1979) com as modificações propostas por Cavalcante \& Ferreira (1983) na última edição do mapa geológico do Ceará.

Tabela 2 - Quadro comparativo das colunas estratigráficas propostas para o Grupo Ubajara

Table 2 - Comparison of the several stratigraphic proposals for the Ubajara Group

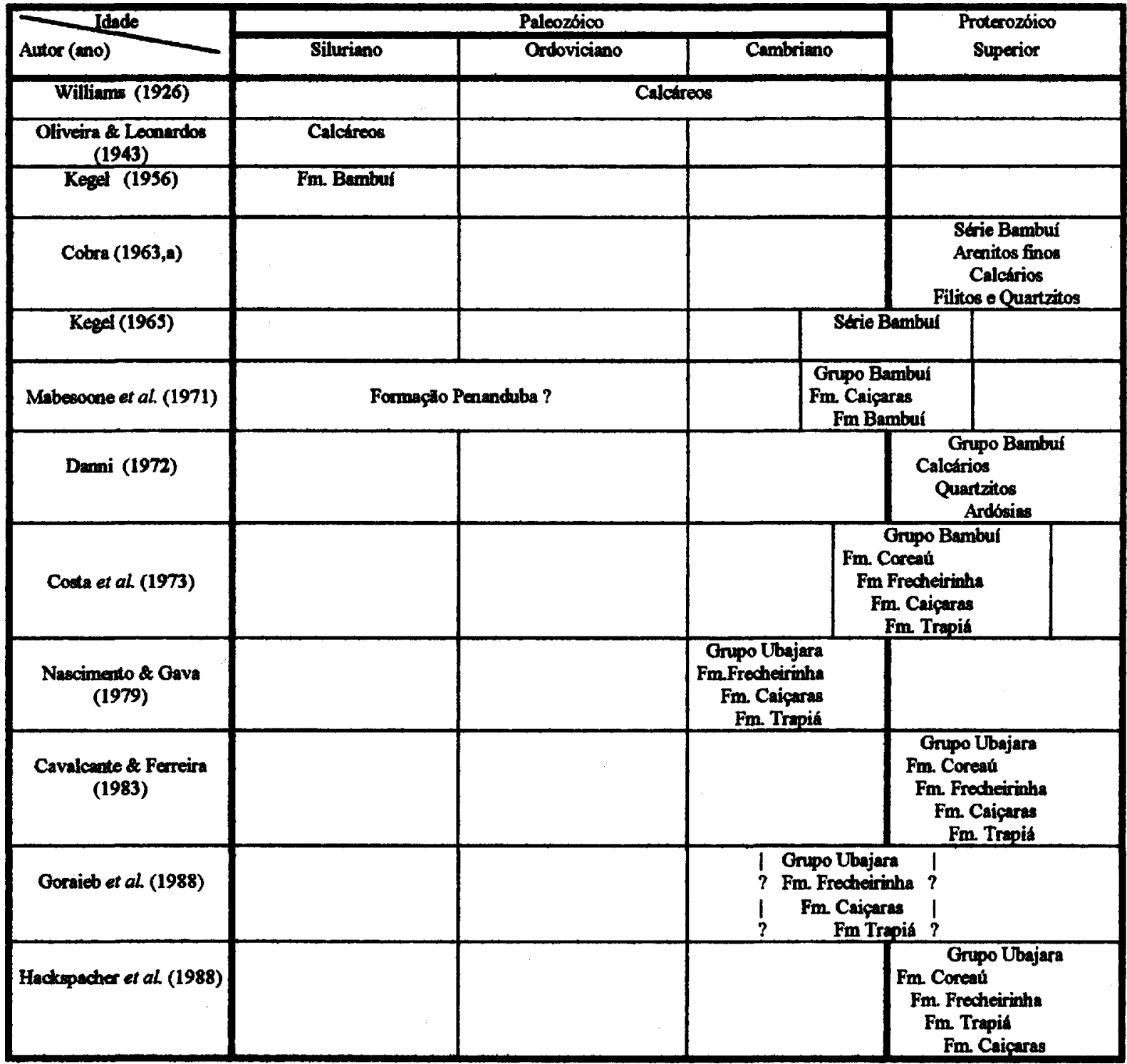


Grupo Martinópole Uma vez mais foi Small (1914) quem descreveu as primeiras rochas que viriam a ser do Grupo Martinópole. A elas, deu-lhes o nome, proposto anteriormente por Crandall (1910), de Série Ceará. Moraes (1924), Williams (1926), Cobra (1963) e Ferreira (1972) mantiveram o mesmo nome para tais litologias. Costa et al. (1973) passaram a designá-las de Pré-cambriano "A". No ano seguinte, Dantas passa-as para Grupo Ceará mantendo-as no Proterozóico Superior. Foi com Brito Neves (1975) que essas rochas passaram a ter o nome que ainda hoje perdura "Grupo Martinópole". Prado et al. (1981) subdividem o Grupo Martinópole nas três formações clássicas ou seja Santa Terezinha constituída por filitos, Covão formada essencialmente por xistos e São Joaquim onde os quartzitos são os principais litótipos e colocam-no no Proterozóico Médio. Torquato et al (1987) retiram a Formação São Joaquim deste grupo e subdividem as duas superiores em membros. A Santa Terezinha passou a constituir-se dos seguintes Membros: Casinha, Vargem e Marfim, e a Covão dos Membros Várzea Grande e Lagoa Grande, tudo no Proterozóico Superior. Oliveira (1987) igualmente retira a Formação São Joaquim do Grupo Martinópole. Santos \& Hackspacher (1992) colocam o Grupo Martinópole no Proterozóico Inferior e adotam uma nova subdivisão, usando
Unidades em vez de Formações, são assim criadas a Unidade basal (Unidade I) que passa a conter quartzo-clorita-sericita xistos, a Unidade II que corresponde em tudo à antiga Formação São Joaquim e as duas últimas III e IV são equivalentes das Formações Covão e Santa Terezinha. Oliveira (1982) coloca o grupo no espaço de tempo compreendido entre o Proterozóico Superior e Médio. Cavalcante (1993) passa-o para o Proterozóico Médio a Inferior. Torquato \& Pedreira (1994), mantêm a mesma coluna de 1987 e passam-no para o Proterozóico Inferior. Em 1995 Fetter et al. datam-no através do método $\mathrm{U} / \mathrm{Pb}$ e obtêm a idade de $808 \mathrm{Ma}$ (Tabela III).

Grupo São Joaquim A história do Grupo São Joaquim começou a delinear-se em 1987, quando Torquato et al. e Oliveira, em trabalhos separados, e com enfoques totalmente diferentes, propuseram o seu desmembramento do Grupo Martinópole. As suas litologias foram inicialmente identificadas por Costa et al (1973) que as individualizaram como Pré-cambriano "B". Como Formação São Joaquim integrada no Grupo Martinópole, foram Prado et al (1981) quem a criaram, no entanto, o nome de Formação São Joaquim como unidade independente, deve-se a Korpershoeck et al (1979).

Tabela 3 - quadro comparativo das colunas estratigráficas propostas para o Grupo Martinópole

Table 3 - Comparison of the several stratigraphic proposals for the Martinópole Group

\begin{tabular}{|c|c|c|c|c|c|}
\hline Idade & \multicolumn{2}{|c|}{ Paleozóico } & \multicolumn{3}{|c|}{ Proterozóico } \\
\hline Autor (Ano) & Indiferenciado & Cambriano & Superior & Médio & Inferior \\
\hline Crandall (1910) & Série Ceará & & & & \\
\hline Small (1914) & & Série do Ceará & & & \\
\hline Moraes (1924) & & & & & Série do Ceará \\
\hline Williams (1926) & & & \multicolumn{3}{|c|}{ Série do Ceará } \\
\hline Cobra (1963) & & & & & Série Ceará \\
\hline Ferreira (1972) & & & Série Cearáa & & \\
\hline Costa et al. (1973) & & & Pre-cambriano " $\mathrm{A}$ " & & \\
\hline Dantas (1974) & & & Grupo Ceará & & \\
\hline Brito Neves (1975) & & & Grupo Martinópole & & \\
\hline $\begin{array}{l}\text { Korpershock } \\
\text { et al. (1979) }\end{array}$ & & & & $\begin{array}{c}\text { Fm. Mambira } \\
\text { Fm. São Joaquim }\end{array}$ & \\
\hline Prado et al. (1981) & & & & $\begin{array}{l}\text { Gr. Martinઠple } \\
\text { Fm Sta Terezinha } \\
\text { Fm. Covđ̃o } \\
\text { Fm. S.Joaquim }\end{array}$ & \\
\hline Torquato et al. (1987) & & & $\begin{array}{l}\text { Gr. Martinopole } \\
\text { Fm. S Terezinha } \\
\text { Mb. Casinha } \\
\text { Mb.Vargem } \\
\text { Mb. Marfim } \\
\text { Fm. Covão } \\
\text { Mb. V. Grande } \\
\text { Mb. L. Grande }\end{array}$ & & \\
\hline Oliveira (1987) & & & \multicolumn{2}{|c|}{$\begin{array}{c}\text { Gr.Martinopole } \\
\text { Fm S Terezinha } \\
\text { Fm. Covão } \\
\end{array}$} & \\
\hline $\begin{array}{c}\text { Santos \& Hackspacher } \\
\text { (1992) }\end{array}$ & & & & & $\begin{array}{c}\text { Grupo } \\
\text { Martinopole } \\
\text { Unidade IV } \\
\text { Unidade III } \\
\text { Unidade II } \\
\text { Unidade I } \\
\end{array}$ \\
\hline Oliveira (1992) & & & \multicolumn{2}{|c|}{$\begin{array}{l}\text { Grupo Martinópole } \\
\text { Fm. Santa Terezinha } \\
\text { Fm. Covão }\end{array}$} & \\
\hline Cavalcante (1993) & & & & \multicolumn{2}{|c|}{ Grupo Martinópole } \\
\hline Fetter et al. (1995) & & & $\begin{array}{l}\text { Gr. Martinópole } \\
\mathrm{U} / \mathrm{Pb}=808 \mathrm{Ma}\end{array}$ & & \\
\hline
\end{tabular}


Torquato et al (1987) além de individualizarem os quartzitos da região como Grupo São Joaquim, também as subdividiram em duas novas Formações, Dom Simão na base e Itacolomi no topo. A Dom Simão, por sua vez, foi desmembrada nos seguintes Membros: Mato Verde com quartzitos puros e Morro do Cascudo onde ocorrem os quartzitos impuros, por vezes bastante micáceos, com intercalações de calcissilicáticas e xistos, e a Itacolomi, em Riacho do Lino com quartzitos de granulometria variável, Paula Pessoa com quartzitos impuros bastante micáceos e Pau Ferro formado por gnaisses com lentes de quartzitos. Mais tarde, Torquato (1995 - em publicação), troca, por questões de prioridade, o nome de Formação Itacolomi para Formação Lamarão.

Oliveira (1987) igualmente subdivide as rochas da Formação São Joaquim, separadas do Grupo Martinópole, mas usa as designações de Unidade I (basal) e Unidade II (topo) (Tabela IV).

Os presentes autores foram dois dos três criadores do Grupo em 1987, deste modo, a sua opinião é que se continue a adotar a divisão indicada.

\section{Unidades estratigráficas de pouca expressão} e/ou de existência duvidosa Além das unidades anteriormente indicadas ainda ocorrem na região quatro conjuntos de rochas metassedimentares (Tabela V) que, para alguns poucos autores formam unidades independentes. São eles: Grupo São José, criado por Prado et al (1981) e subdividido por Oliveira (1987) em quatro seqüências, constituído por uma seqüência metapsamítica-pelítica-carbonática, numeradas da base para o topo de I a IV. Oliveira et al (1988) tecem considerações sobre os Grupos São José e Martinópole, Santos \& Hackspacher (1992) e Santos (1993) confirmam a presença deste grupo.

A Formação Penanduba, formada por conglomerados basais capeados por um arenito fino ambos fortemente silicificados, foi proposta por Mabesoone et al (1971) e, ninguém mais a individualizou, sempre passou a fazer parte da Formação Trapia ou Serra Grande.

A Formação Olho d'Água do Caboclo onde ocorrem metarenitos finos capeados por metarenitos médios a grossos com intercalações de metassiltitos, ardósias e vulcânicas foi proposta e descrita exclusivamente por Hackspacher et al (1988).

Os metassedimentos Casinha foram propostos por Oliveira (1987) para designar um conjunto de rochas que designa de ardósias diamictíticas, metarenitos, metasiltitos e ardósias siltosas que ele desmembrou da Formação Covão. Foram descritos novamente por Oliveira et al (1988) e por Oliveira (1992).

Os presentes autores acham que nenhum destes litótipos pode ser encarado conforme o descrito. O Grupo São José trata-se de rochas pertencentes ao Grupo Martinópole, o próprio Oliveira disse em 1992 ser extremamente difícil a sua separação. A Formação Penanduba deve ser encarada como parte integrante da Formação Trapia do Grupo Ubajara. A Formação Olho d'Água do Caboclo é igualmente parte integrante do Grupo Ubajara. e os metassedimentos Casinha pertencem, sem dúvida, à Formação Covão do Grupo Martinópole.

\section{TECTÔNICA DO DOMÍNIO DO MÉDIO COREAÚ}

Apesar de serem várias as unidades litoestratigraficas aflorantes dentro do Domínio do Médio Coreaú (NW do Ceará), de uma forma genérica e para fins de reconstituição dos elementos tectônicos, podemos separar esse Domínio em dois conjuntos distintos, um formado pela infraestrutura (embasamento gnaíssico-granulitico) e outro supracrustal, constituído pelos metassedimentos dos Grupos São Joaquim, Martinópole, Ubajaras e Jaibaras.

Tectônlca da Infraestrutura A infraestrutura conforme aqui definida, corresponde aos gnaisses, migmatitos e granulitos constituintes do Complexo de Granja, sendo limi-

Tabela 4 - Quadro comparativo das colunas estratigráficas propostas para o Grupo São Joaquim. Para dados anteriores a 1979, ver Tabela 3.

Table 4 - Stratigraphic columns proposed for the São Joaquim Group. See Table 3 for data prior to 1979.

\begin{tabular}{|c|c|c|c|}
\hline Idade & \multicolumn{3}{|c|}{ PROTEROZOICO } \\
\hline Antor (Ano) & Superior & Médio & Inferior \\
\hline Costa et al. (1973) & & $\begin{array}{c}\text { Pro-Cambriano } \\
\text { "B" }\end{array}$ & \\
\hline $\begin{array}{l}\text { Korpenthoeck } \\
\text { et al. (1979) }\end{array}$ & & & Fm. Sxo Joaquim \\
\hline Prado et al (1981) & & $\begin{array}{l}\text { Grupo Martinópole } \\
\text { Formaclo Sao Joaquim }\end{array}$ & \\
\hline Torquato et al (1987) & & & $\begin{array}{l}\text { Grupo Sao Joaquim } \\
\text { Fm. Itacolomi } \\
\text { Mb. Pau Ferro } \\
\text { Mb. Paula Pessoa } \\
\text { Mb. Riacho do Lino } \\
\text { Fm. Dom Simalo } \\
\text { Mb. Morro do Cascudo } \\
\text { Mb. Mato Verde }\end{array}$ \\
\hline Oliveira (1987) & & $\begin{array}{r}\mathbf{F m} . \mathbf{S} \\
\mathrm{Un} \\
\mathrm{Un}_{\mathrm{n}} \\
\end{array}$ & $\begin{array}{l}\text { Joaquim } \\
\text { ade II } \\
\text { lade I }\end{array}$ \\
\hline $\begin{array}{l}\text { Torquato } \\
\text { (eate traballho) }\end{array}$ & & & $\begin{array}{l}\text { Grupo Slo Joaquim } \\
\text { Fm. Lamaráo } \\
\text { Mb. Pau Ferro } \\
\text { Mb. Paula Pessoa } \\
\text { Mb. Riacho do Lino } \\
\text { Fm. Dom Simåo } \\
\text { Mb. Morro do Cascudo } \\
\text { Mb. Mato Verde } \\
\end{array}$ \\
\hline
\end{tabular}


Tabela 5 - Quadro comparativo das colunas propostas para o Grupo São José e Formação Penanduba

Table 5 - Comparison of the the several stratigraphic proposals for the São José Group and Penanduba Formation

\begin{tabular}{|c|c|c|c|c|c|}
\hline Idade & \multicolumn{4}{|c|}{ PALEOZOICO } & Proterozóico \\
\hline Autor(ano) & Siluriano & Devoniano & Ordoviciano & Cambriano & Superior \\
\hline \multicolumn{6}{|c|}{ GRUPO SAO JOSE } \\
\hline $\begin{array}{c}\text { Prado et al. } \\
\text { (1981) }\end{array}$ & & & & & Grupo Sāo Jose \\
\hline Oliveira (1987) & & & & & $\begin{array}{l}\text { Grupo Săo losé } \\
\text { Sequencia IV } \\
\text { Sequetncia III } \\
\text { Sequencia II } \\
\text { Sequiencia I }\end{array}$ \\
\hline \multicolumn{6}{|c|}{ FORMACXO PENANDUBA } \\
\hline $\begin{array}{l}\text { Mabesoone et } \\
\text { al. (1971) }\end{array}$ & Formaça & enanduba & & & \\
\hline $\begin{array}{c}\text { Costa et al. } \\
\text { (1973) }\end{array}$ & & & & \multicolumn{2}{|c|}{$\begin{array}{c}\text { Grupo Bambú } \\
\text { Formac ào Trapia }\end{array}$} \\
\hline $\begin{array}{l}\text { Hackspacher } \\
\text { et al. (1988) }\end{array}$ & $\begin{array}{l}\text { Formaçto } \\
\text { Serm Grande }\end{array}$ & & & & \\
\hline
\end{tabular}

tada em sua porção sul pelo Lineamento Sobral-Pedro II ( Lineamento Transbrasiliano).

Santos (1993), propõe uma evolução tectônica para o embasamento da região constituída por pelo menos cinco fases deformacionais distintas $\left(\mathrm{D}_{\mathrm{n}-2}, \mathrm{D}_{\mathrm{n}-1}, \mathrm{D}_{\mathrm{n}}, \mathrm{D}_{\mathrm{n}+1}, \mathrm{D}_{\mathrm{n}+2}\right)$. Conforme dados desse mesmo autor, uma sucessão de três fases mantêm lineações de estiramento mineral com direções NE- SW e mergulhos suaves para NE ou SW, o que ao nosso ver corresponderia apenas a um evento, ao contrário de três, além disto , indica o predomínio de um regime direcional contendo componentes tangenciais (Transpressão ?). Assim , as lineações minerais NE-SW com mergulhos de $10^{\circ}$ a $15^{\circ}$ para NE ou SW, estariam associadas a um evento contendo componentes direcionais e tangenciais sob regime inicialmente dúctil . Por outro lado, dados de atitudes de lineações de estiramento a norte da zona de cisalhamento de Granja $\left(170^{\circ}\right.$ de azimute com mergulhos de $35^{\circ}$ para SE), sugerem uma tectônica tangencial pretérita , com movimentação para NNW. Adicionalmente diversas dobras fechadas com vergência para NW e transposição de flancos das mesmas, concorrem nesse sentido.

Com relação ao evento (ou eventos) responsável pelo alçamento dos litótipos granulíticos e seu posicionamento em níveis crustais superiores, duas possibilidades adquirem relevância, uma ligada à composição da movimentação direcional e tangencial num mesmo evento tectônico com as zonas de cisalhamento correspondendo a rampas oblíquas ( Gama Jr. 1992 ) , a outra, evoluiria em dois estágios distintos, inicialmente com uma tectônica tangencial para NW, seguida de bloqueio nessa direção, após o qual cedeu a manifestações de uma nova fase transcorrente com movimentação NE-SW.

A metaestabilidade das fases de elevada temperatura nos granulitos, evoluindo para condições frágeis, sugere um estágio simples evolutivo, finalizando com o soerguimento dos granulitos durante o Ciclo Brasiliano, de forma similar à evolução descrita para os granulitos Pan-Africanos do Benin (Caby et al. 1991).

Tectônica das Seqüências Supracrustais Os aspectos tectônicos aqui abordados serão restritos ao conjunto de rochas supracrustais pertencentes aos Grupos São Joaquim, Martinópole e Ubajara.

Os quartzitos do Grupo São Joaquim exibem foliação penetrativa bem marcada, e sobre os planos da mesma, ocorre uma lineação de estiramento mineral $\left(\mathrm{L}_{\mathrm{n}}\right)$, reconhecida em escala mesoscópica, a qual exibe encurvamento gerando feições similares às desenvolvidas por dobras em bainha. Nos quartzitos mais "aluminosos", a trama linear é marcada pela orientação de cianita paralelas a interseção entre $\mathrm{S}_{0}$ e o plano de foliação. Dobras intrafoliais em pequena escala são também observadas. Outra lineação $\left(\mathrm{L}_{\mathrm{n}+1}\right)$, encontra-se em alto ângulo, perpendicular a lineação anterior, com mergulhos para SE e formada pela recristalização do quartzo, sendo evidenciada através do estudo da trama cristalográfica (Santos, 1993). As assembléias de pico metamórfico estão bem preservadas, presentes pela associação de cristais boudinados de cianita, circundados por estaurolita de crescimento estático. Por outro lado, há indicações da superposição de um evento em condições metamórficas mais brandas, registrado pela cristalização de quartzo em baixas temperaturas , e substituição de cianita por pirofilita (Caby et al. 1991).

Os filitos do Grupo Martinópole apresentam marcante clivagem ardoseana, dentro da qual, além da orientação de clorita e sericita são encontrados níveis milimétricos de quartzo ribbons. Essa clivagem foi redobrada e gerou crenulações com direção compressional ENE ( Caby et al. 1991). Sobre o plano dessa foliação, desenvolve-se lineação mineral de estiramento formada por micas e sombras de pressão ao redor de minerais opacos, sub-horizontal com direção de NE-SW a E-W , indicando movimentação direcional do conjunto. Perpendicular a essa direção, ocorrem redobramentos isoclinais milimétricos com feições similares a dobras em bainha, podendo representar marcadores estruturais anteriores ao "trend" NE-SW.

Indicadores cinemáticos (assimetria de dobras e rotações de pórfiroclastos) e inversão de camadas, sugerem cavalgamentos do conjunto supracrustal São Joaquim e Martinópole, por sobre as rochas do embasamento (fig.2).

Conforme Santos (1993), a movimentação de blocos em transcorrências NE-SW, evoluiriam para cavalgamentos em rampa lateral por mecanismos transpressivos, originando estruturas em flor positivas, nas litologias do Grupo Martinópole, com fuga de material para NW e SE.

Os elementos estruturais registrados nas supracrustais São Joaquim e Martinópole remetem ainda a outra possibilidade de quadro evolutivo, dentro do qual, uma tectônica tangencial (Dn) afetaria inicialmente todo o conjunto, progressivamente a movimentação de blocos para NW seria bloqueada gerando encurtamento com retro-empurrões mais a SE, seguindo-se então o predomínio direcional da tectônica $(\mathrm{Dn}+1)$.

Uma tectônica pós-molássica gerou dobras com planos axiais verticais e eixos com forte caimento, associados a uma insipiente clivagem ardoseana nas rochas do Grupo Ubajara. As superfícies horizontais de estilólitôs nos calcários do Grupo Ubajara indicam moderado encurtamento vertical ( Caby et al. 1991). A deformação das litologias do Grupo Ubajara, de acordo com Caby et al. (1991), estaria ligada ao soerguimento do embasamento de alto grau metamórfico adjacente, no Cambriano (transição Neoproterozóico/Cambriano) enquanto bacias intramontanas eram preenchidas e fechadas.

Dados geocronológicos de Fetter et al. (1995) e Santos et al. (1995), obtidos por U/Pb em zircões de rochas metavulcânicas ácidas intercaladas nos metassedimentos do Grupo Martinópole, indicam idade de sedimentação em torno dos $800 \mathrm{Ma}$, dessa forma toda a evolução tectono-metamórfica teria o seu desenvolvimento no decorrer do Neoproterozóico. Adicionalmente, esta ultima idade posiciona temporalmente, lado a lado, os Grupos Martinópole e Ubajara, onde o primeiro corresponderia originalmente à facies siliciclástica proximal e o segundo a facies distais com sedimentação plataformal.

ARCABOUÇO GEOTECTÔNICO A história geotectônica da região do Médio Coreaú começou a ser escrita por Williams (1926), foram, no entanto, Oliveira \& Leonardos (1943) quem pela primeira vez citaram que o Professor Charles Schuchert da Universidade de Yale, tinha proposto que a região era parte do Geossinclíneo Franciscano. Aparece assim 


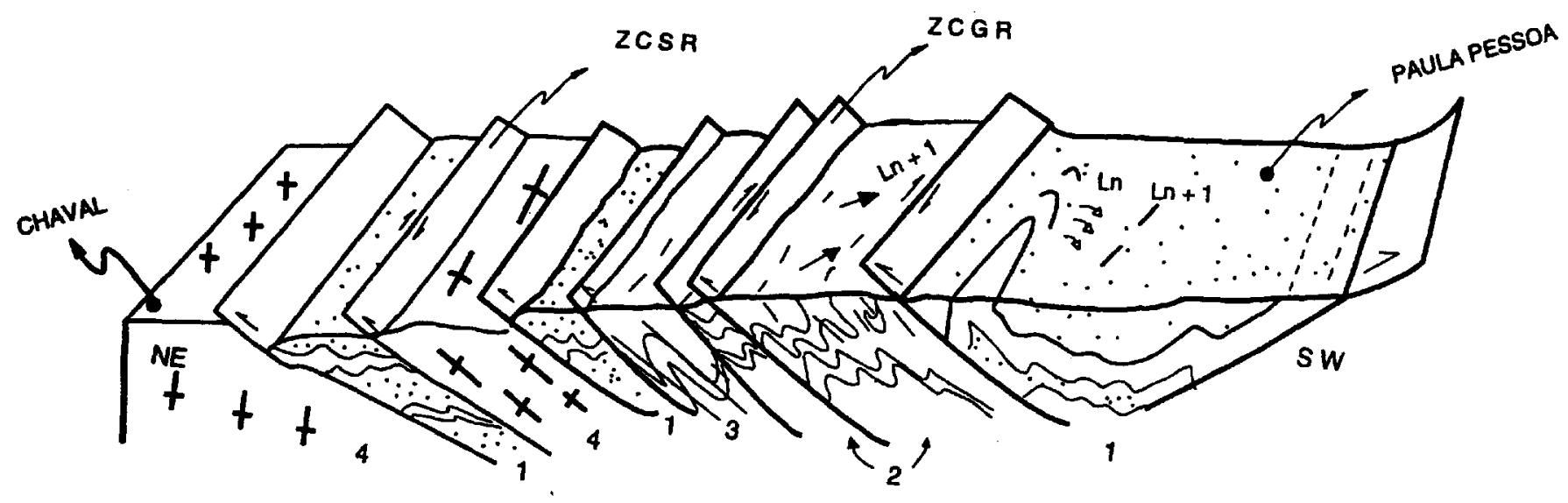

\author{
1 - Xistos, Quartzitos (Grupo Martinópole/São Joaquim) \\ 2 - Gnaisses, Migmatitos (Complexo Granja) \\ 3 - Granulitos (Comploxo Granja) \\ 4- Granito Chaval \\ ZCSA - Zona de Cisalhamento de Santa Rosa \\ ZCGR - Zona de Cisalhamento de Granja \\ Cidade
}

Figura 2 - Bloco-diagrama esquemático do extremo NW do Ceará, mostrando uma seção NE-SW

Figure 2 - Schematic block-diagram of the northwestern Ceará showing a NE-SW section

o nome de geossinclíneo para caracterizar geotectônicamente as rochas/ambiente da região (Tabela VI). Almeida (1968) ao descrever no nordeste as rochas da Série Ceará, define o Ciclo Caririano que, mais tarde passa para faixa dobrada Caririana e mostra bem as ligações estruturais entre o Lineamento de Sobral- Pedro II no Brasil e as falhas de Alibory e Bifur em África e as seqüências do tipo Jaibaras com idênticas africanas.

Como um todo, temos quatro modelos principais que se ocuparam da evolução geotectônica do nordeste do Brasil, logo, do Domínio Rio Coreaú. Podemos descrevê-los de acordo com os seus autores. Os trabalhos pioneiros devem-se a Kegel $(1958,1965)$, nas décadas de 70 e 80 foram as idéias de Brito Neves $(1973,1975$ e 1983) que vieram mudar de forma radical o entendimento da estruturação geotectônica do nordeste. Recentemente Jardim de Sá (1984) e Abreu et al. $(1988,1990)$, abordaram o assunto com uma conceituação totalmente diferente.

O primeiro esboço geotectônico da região, como anteriormente mencionado, foi apresentado por Kegel et al. (1958) que descreveram toda a área sob o nome de Corpo Orogênico do Coreaú. Em 1965 Kegel, independentemente de suas características geológicas, divide todo o Estado do Ceará em oito blocos tectônicos (Fig.3) limitados por grandes lineamentos ou falhamentos. O chamado Bloco do Coreaú onde se inserem as rochas agora discutidas, está limitado a sudeste pelo Lineamento Sobral-Pedro II e ali contata com os blocos de Itapagé, Santa Quitéria e Acaraú.

A estruturação geotectônica do Nordeste, observada sob o ponto de vista de modelos modernos, só começou a delinear-se com Brito Neves (1973) quando este procurou sistematizar de forma mais ou menos independente de nomes ou conceitos os grandes traços do Nordeste do Brasil. Para Brito Neves (op.cit.) a área caririana foi o resultado "da tectogênese e consolidação, no ciclo brasiliano, de uma ampla "região geossinclinal" ou poligeossinclinal desenvolvida sobre $e$ marginal a uma antiga plataforma, em grande parte regenerada, e da qual muito herdou tectonicamente". Os, hoje consagrados, nomes de "faixas de dobramentos" e "altos tectônicos" foram introduzidos neste trabalho. A descrição da
Tabela 6 - Evolução da nomenclatura geotectônica no noroeste do Ceará

Table 6 - Evolution of the geotectonic nomenclature of the northwestern Ceará

\begin{tabular}{|c|c|}
\hline Oliveire \& Leonardos (1942) & Geossinclíneo Franciscano \\
\hline Kegel et al. (1958) & Corpo orogénico de Coreau \\
\hline Kegel (1965) & Bloco orogénioo de Coreaci \\
\hline Almeida (1968) & Ciclo Caririano \\
\hline Almeida et al (1973) & Cinturäo Dobrado Caririano \\
\hline Brito Neves (1973) & $\begin{array}{l}\text { Regiưo do Módio Coreaú } \\
\text { (Faixas de dobramentos e Altos tectôniós) }\end{array}$ \\
\hline Costa et al. (1973) & Miogoossinclinal da lbiapabs (Grupo Bambui) \\
\hline Brito Neves (1975) & $\begin{array}{l}\text { Regialo de Dobramentos Nordeste } \\
\text { Macipo de Granja } \\
\text { Faixa de Dobramentos do Módio Coreaú }\end{array}$ \\
\hline Almeida et al. (1977) & $\begin{array}{l}\text { Provincia Borborema } \\
\text { Sistema de dobramentos do Médio Coreaú }\end{array}$ \\
\hline Mello et al. (1978) & Provincia estrutural Caririana \\
\hline Brito Neves (1983) & $\begin{array}{l}\text { Dominio Rio Coreaú } \\
\text { Macico de Granja } \\
\text { Sistema Médio Coreaú }\end{array}$ \\
\hline Abreu et al (1988) & $\begin{array}{l}\text { Cinturão de Cisalhamento do Noroeste do Ceará } \\
\text { | Norceste } \\
\text { Dominios | Mediano } \\
\text { | Sudeste } \\
\end{array}$ \\
\hline Jardim de Sá (1994) & Frixa Noroeste do Ceard \\
\hline Gams Júnior et al. (1990) & Zana de Cisalhamento de Granja \\
\hline Vauchez et al (1995) & Zona de Cisaihamento de Sobral \\
\hline Silva Filho (1995) & Pargplataforma do Jaguaribe \\
\hline
\end{tabular}

área agora conhecida como Médio Coreaú foi inclusa na "Região Ocidental do Ceará".

$\mathrm{O}$ arcabouço geotectônico da região nordeste do Brasil teve grande impulso a partir da tese de doutoramento de Brito Neves (1975) pois foi nela que o autor, pela primeira vez, "arrumou" as principais litologias e as ligou a determinadas feições geotectônicas cuja história e evolução estavam em foco naquela altura. Os grandes traços estruturais serviram a Brito Neves, tal como já tinham servido a Kegel (1965), para organizar sob a égide de conceitos atuais o embasamento 


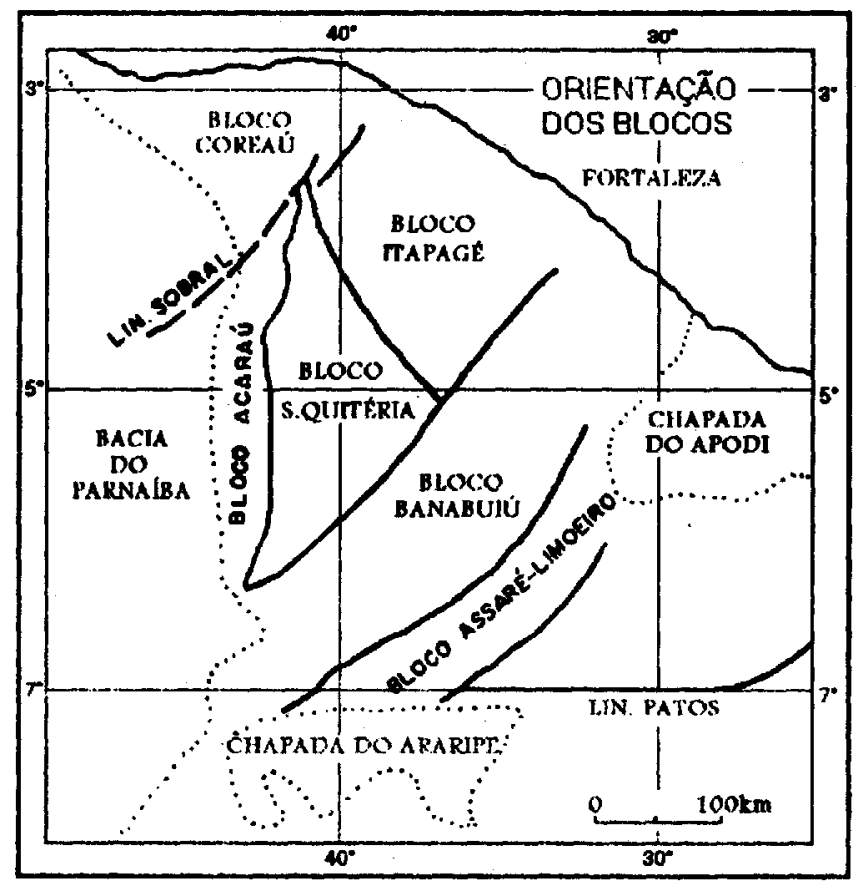

Figura 3 - Blocos tectônicos do Estado do Ceará (Kegel 1965) Figure 3 - Tectonic blocks of the Ceará State (Kegel 1965)

nordestino de modo sistemático. Deste modo, todo o noroeste cearense foi dividido no Maciço de Granja e na Região do Médio Coreaú. O Maciço de Granja foi individualizado como sendo um "alto tectônico" brasiliano, relacionado provavelmente com uma projeção do Cráton de São Luís. Na sua borda sudeste o maciço está recoberto por conjuntos pré-cambrianos ou eo-paleozóicos provenientes de diferentes estágios de evolução das faixas dobradas que o margeiam. Estas seqüências foram chamadas de singeossinclinais e depositaram-se sob a forma de autênticos sulcos externos (Ubatuba e Timbaúba) em discordância estrutural e erosiva sobre as rochas do maciço. "A presença de sulcos externos sobrepostos, antefossas e intensa tectônica rutural confere a borda sudeste do Maciço de Granja características afins de um sistema tectônico marginal da plataforma. A leste da chamada "zona de cisalhamento de Jaguarapi" (Costa et al. 1973), onde se situam as antefossas mencionadas, não se conhece nada equivalente ao contexto lito-estrutural do maciço de Granja ".

O nome de Região do Médio Coreaú foi dado por Brito Neves (pp. cit) em função da complexidade e grande mobilidade ruptural diferenciando-se assim das fases mais antigas caracterizadas por uma tectônica plástica. Toda a região representa um mega-fragmento afundado e ali preservado entre dois blocos relativamente rígidos "sob o comando de um importante lineamento tectônico e das falhas a ele subordinadas". O Grupo Martinópole seria o representante de um desenvolvimento miogeossinclinal que teve como antepaís o Maciço de Granja (e que, sobre ele funciona como cobertura singeossinclinal). Acha-se disposto em dois sulcos separados pelo "horst de Tucunduba". As rochas do que, naquela altura, se chamava de Grupo Bambuí e hoje se conhece sob a designação de Grupo Ubajara, eram, para o autor, as fases sucessivas da pré-inversão de um ciclo de sedimentação geossinclinal clássico (Trapiá, Caiçaras e Frecheirinha) e da pós-inversão (Coreaú). "Os granitos Meruoca e Mucambo constituem o fecho deste desenvolvimento, antecedendo a fase pós-geossinclinal, representada, com muita propriedade, pelo Grupo Jaibaras".

O Grupo Jaibaras instalou-se no sistema de grabens condicionados pela falha de Sobral a sudeste e de Jaguarapi a noroeste. Geotectonicamente é um exemplo clássico de sedimentação molássica, fundamentalmente imatura e continental, com forte vulcanismo fissural associado. O estágio de transição está presente através das Formações Massapê e Pacujá que representam o desmantelamento e erosão dos relevos jovens recém criados. $\mathrm{O}$ vulcanismo Parapui foi o resultado da maximização dos esforços tracionais e nele predominam os tipos básicos e intermediários. A Formação Aprazível corresponde ao episódio terminal do estágio de consolidação. Quando Brito Neves escreveu a sua tese de Livre Docência (1983), já existia o conceito de Província Borborema. Neste trabalho o autor apresenta para ela uma dualidade de tipos litoestruturais, os terrenos metassedimentares ou cinturões metamórficos - Os Sistemas de dobramentos, e os terrenos gnaíssico-migmatíticos e/ou migmatítico-graníticos.

Sob o nome de Domínio Rio Coreaú, Brito Neves (1983) engloba agora toda a região noroeste do Ceará (o que anteriormente havia chamado de Maciço de Granja e Faixa de Dobramentos do Médio Coreaú). O maciço ou bloco de Granja está descrito como sendo parte intrínseca do Cráton de São Luís não só pelas similaridades litológicas mas também por ambos se situarem sob um mesmo alinhamento estrutural "Arco Ferrer -Urbano Santos - Guamá".

O Domínio do Rio Coreaú passa a ser subdividido em duas faixas, uma a noroeste (Martinópole) e a outra a sudoeste (Bambuí-Jaibaras), separadas por um alto tectônico central, o "Horst de Tucunduba". As duas faixas estão descritas com todo o pormenor disponível na época. Dentro do esquema clássico de evolução geossinclinal, na faixa sudeste as Formações Trapiá e Caiçaras foram identificadas como sendo a seqüência terrígena basal com as respetivas fácies psamítica (proximal) e pelítica (distal). A Formação Frecheirinha corresponde em tudo à seqüência carbonática. A Formação Coreaú marca a seqüência terrígena superior. O Grupo Jaibaras está descrito como o resultado de fases tracionais da tectônica brasiliana. "No seu enquadramento estrutural e litoestratigráfico o Grupo Jaibaras consubstancia radical mudança na ambiência geotectônica da região. O surgimento de "rift-valleys", a sedimentação de caráter ortomolássico e o vulcanismo fissural e extrusivo associado, a intensa tectônica de blocos por reativação vertical de geofraturas do substrato, etc., são diagnósticos típicos dos estágios de transição... para condições ortoplataformais (pós-Siluriano).

Jardim de Sá (1984) procura fazer uma nova abordagem na evolução geotectônica proterozóica da Província Borborema. Começa por descrever a geologia africana pré-deriva adjacente ao nordeste brasileiro. Ao fazer a correlação com a área agora em discussão, diz "Não parece haver boa correspondência no NW do Ceará com a zona de sutura do Oeste do Hoggar, com suas rochas máficas-ultramáficas e terrenos vulcanossedimentares e de alta pressão emparelhados. Por outro lado, se a sutura ocorremos moldes da Faixa Dahomey, deveríamos esperar supracrustais neoproterozóicas pouco deformadas e metamorfizadas, empurradas ou em discordância sobre os gnaisses de Granja, os quais representariam a área cratônica; esta configuração nos parece se adaptar aos Grupos Martinópole e Ubajara, e a norte do mesmo as datações sugerem a presença de metamorfismo e granitos brasilianos. Se datações por métodos mais confiáveis confirmarem a idade destes últimos eventos citados, será necessário admitir que, se a sutura continua no Brasil ela o faz abaixo da cobertura Paleozóica do Parnaíba e das bacias costeiras. Por outro lado, confirmando-se uma idade antiga (Transamazônica?) para o granito de Chaval, pode-se admitir um modelo de sutura em niveis mais profundos que no Dahomey, com a superposição de uma pilha de nappes incluindo embasamento e supracrustais, ... Neste caso a sutura principal (sutura críptica?) poderia se situar em algum ponto entre Granja e Sobral, ou mesmo a SE desta última, ainda que os 
dados de mapeamento não ofereçam suporte a essa especulação". Continuando, o autor passa a interpretar, ou melhor, reinterpretar as características geotectônicas da Província Borborema. Começa por dizer que a sua evolução está correlacionada com um Ciclo de Wilson que abrangeria os Crátons Oeste Africano e São Luís. Assim, a parte oeste da Província (a que nos interessa), sofreu inicialmente um desenvolvimento do tipo Margem Andina, evoluindo, conjuntamente com o restante da Província para uma ambiente tipo platô Tibetano. $\mathrm{O}$ estágio de margem deverá ter uma idade superior a $700 \mathrm{Ma}$, ali deverá estar o Grupo Ubajara como seqüência plataformal, sucedida por depósitos flysch de turbiditos e vulcânicas (Grupo Martinópole), neste caso, o Martinópole deveria ter uma idade neoproterozóica. No estágio de colisão principal, entre os 700 e os $600 \mathrm{Ma}$, a deformação brasiliana reflete uma compressão NW que vai provocar espessamento crustal dando assim origem ao Estágio de Platô Tibetano.

As unidades litológicas aflorantes a norte do Lineamento de Sobral-Pedro II, têm como feição tectônica marcante diversas megazonas de cisalhamento de direção NE-SW, as quais imprimem um forte condicionamento aos elementos estruturais planares e lineares gerando faixas expressivas de tectonitos. A este conjunto de unidades, Abreu et al (1988) designaram por "Cinturão de Cisalhamento Noroeste do Ceará".

Com base em critérios litoestruturais, Abreu et al. (1988), compartimentam o Cinturão de Cisalhamento NW do Ceará, em três domínios distintos denominados por: Noroeste, Mediano e Sudeste (fig.4). O Domínio Noroeste é composto pelos granitóides Chaval e Pedra do Sal e em menor proporção por rochas xistosas miloníticas. Diversas zonas de cisalhamento frágeis-ducteis direcionais, de pequenas dimensões estão presentes, e exibem forte ângulo de mergulho com atitudes para nordeste e noroeste. O Domínio Mediano compreende quatro subáreas como segue: subárea I, englobando litótipos granulíticos em sua maioria, gnaisses migmatizados e corpos anfibolíticos; a subárea II, com predomínio de gnaisses tonalíticos e porções subordinadas de gnaisses calcissilicáticos, anfibolitos, quartzitos e xistos; na subárea III ocorrem de modo expressivo as rochas supracrustais dos Grupos Martinópole e São Joaquim; já a subárea IV tem como aspecto principal a lenticularização de supracrustais e de gnaisses migmatíticos, além de faixas expressivas de anfibolitos. Por fim, no Domínio Sudeste são encontradas rochas dos Grupos Ubajara e Jaibaras e dos corpos graníticos intrusivos de Meruoca e Mucambo. Dentro deste quadro, segundo os autores acima citados, dois conjuntos litoestruturais pré-cambrianos podem ser claramente separados na região noroeste do Ceará: Conjunto 1 formado pelos complexos gnáissicos de médio e alto graus, e supracrustais do Grupo Martinópole, as quais compreendem uma história evolutiva antiga e complexa, com desenvolvimento de crosta siálica constituída por terrenos de médio e alto grau metamórfico, e granitos associados, representando a infraestrutura com superposição da bacia Martinópole. Neste conjunto, importantes deslocamentos em sistemas de rampas laterais para sudoeste, desmembram e imbricam as unidades rochosas, assim, com aloctonismo geral, alçariam as rochas de alto grau para níveis crustais mais rasos, caracterizando uma inversão das isógradas. Conjunto 2 - Grupos Ubajara, Jaibaras e granitos intrusivos (Meruoca e Mucambo), os quais tem desenvolvimento no contexto de uma tectônica direcional com o embaciamento e a ascensão das intrusões sob regime trans tensional.

Abreu (1990), redefine os Domínios do Cinturão de Cisalhamento NW do Ceará, modificando a denominação das subáreas III e IV para Domínio Granja-Senador Sá e Domínio Ubajara-Jaibaras respectivamente.

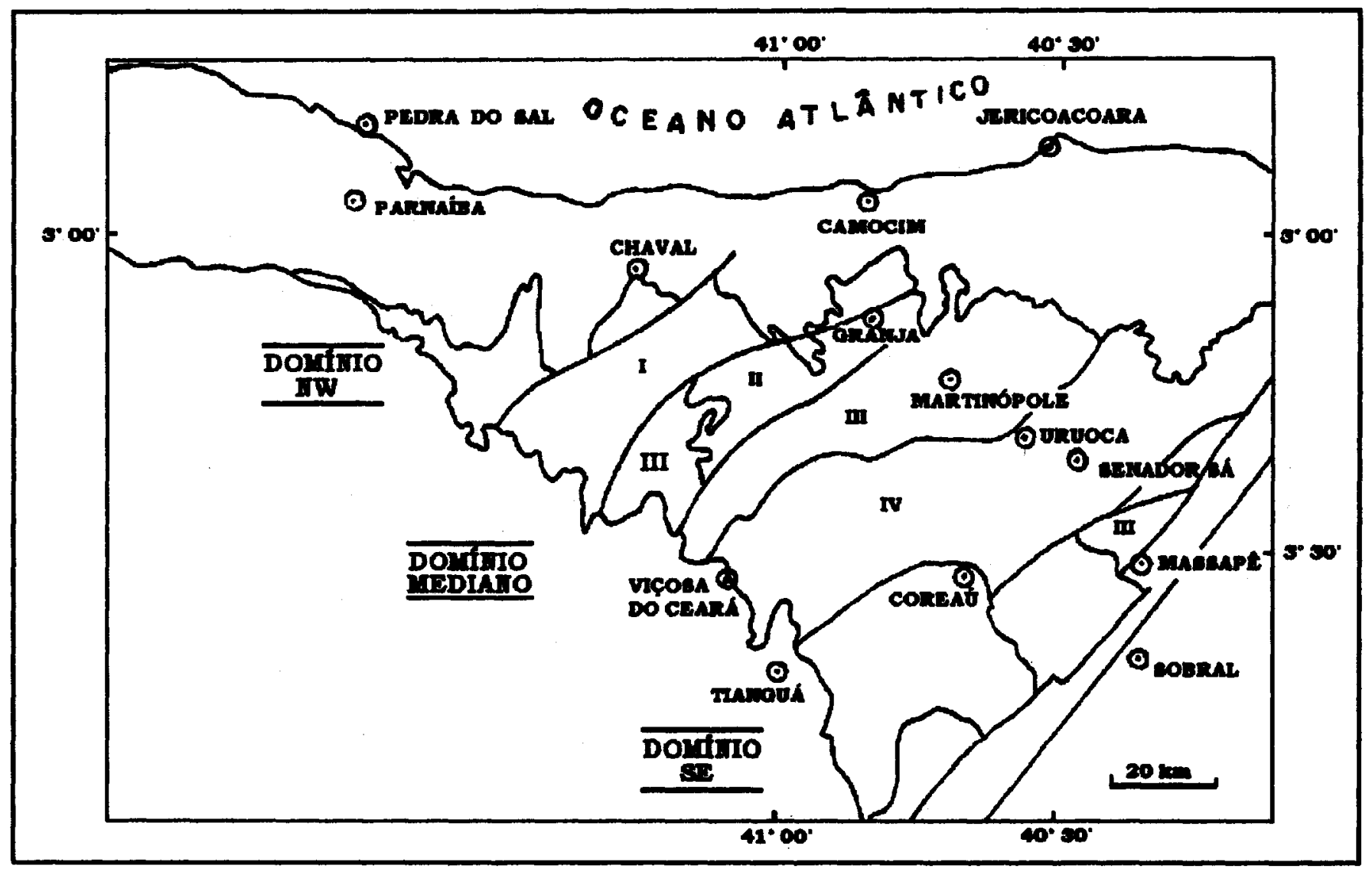

Figura 4 - Diferentes domínios estruturais do noroeste do Ceará (Abreu et al 1988)

Figure 4 - Diferent structural domains of the norhwestern State of Ceará (Abreu et al. 1988) 


\section{REFERÊNCIAS}

ABREU, F. de A.M. de 1990. Evolução geotectônica do Pré-Cambriano da região meio norte do Brasil e sua correlação com a África ocidental. Tese de Doutorado. Belém, Centro de Geociências - UFPa. 384p.

ABREU, F. de A.M.de,; GAMA Jr., T.G.; GORAYEB, P.S. de S.; HASUI, Y. 1988. O cinturão de cisalhamento noroeste do Ceará. In: Congr. Latinoamericano de Geologia, 7. Belém, 1988. Anais... Belém, SBG. p.20-34.

ALMEIDA, F.F.M. de, 1968. Precambrian geology of North-eastern Brazil and West Africa and the theory of continental drift. Natural Resources Research, VIII. Proceedings of the Simposium on the Granites of West Africa. UNESCO, p. 151-162.

ALMEIDA, F.F.M. de ; AMARAL, G.; CORDANI, U.G.; KAWASHITA, K. 1973. The Precambrian Evolution of the South American Cratonic Margin South of the Amazonic River. In: Nairn, A. E. M. ed. The ocean basins and margins. V. 1: p. 416-446.

ALMEIDA, F.F.M. de.; HASUI, Y.; BRITO NEVES, B.B. de, FUCK, R. A. 1977. Províncias estruturais brasileiras. In: Simp. Geol.do Nordeste, 8 Campina Grande, 1977. Atas ... Campina Grande, SBG. Núcleo Nordeste, Bol. 6:363-391.

AUSTRAL / CARAIBA METAIS. 1981. Projeto Ceará. Relatório final. Caraiba metais S.A. Salvador, (inédito)

BRITO NEVES, B.B. de 1973. Elementos da geologia pré-cambriana do Nordeste oriental. In: Cong. Bras. Geol., 27. Aracaju, 1973. Anais.. Aracaju, SBG. v.2. p. 105-133.

BRITO NEVES, B.B. de, 1975. Regionalização geotectônica do Pré-cambriano Nordestino. Tese de Doutorado apresentada ao IG/USP. São Paulo. 198 p.

BRITO NEVES, B.B. de, 1983. O mapa geológico do Nordeste Oriental (escala 1/1.000.000). Tese de Livre Docência. IG/USP. São Paulo. 177 $\mathrm{P}-$

CAB Y, R.; SIAL.A.N.; ARTHAUD, M.H.; VAUCHEZ, A. 1991. Crustal evolution and the Brasiliano orogeny in Northeasth Brazil. In: R.D. Dallmeyer \& J.P. Lécorché. Eds. The West African Orogens and Circum-Atlantic Correlatives. Springer-Verlag. p. 373-397.

CAVAlCANTE, J. de C. 1993. Estratigrafia Precambriana do Estado do Ceará - Uma síntese. In: Simp. Geol. do Nordeste. 15. Natal, 1993. Atas... Natal, Boi. Núcleo Nordeste da SBG. v. 13. p. 313-316.

CAVALCANTE, J. de C. \& FERREIRA, C. A. 1983. Mapa geológico do Estado do Ceará. Escala 1/500.000, MME. CPRM/DNPM.

COBRA, R. Q. 1963,a. Estudo da estratigrafia, tectônica, ocorrências minerais e recussos d'água do nordeste do Ceará. Recife. Sudene. Dep. Rec. Naturais. Relatório Interno. 36 p.

COSTA, M.J.; FRANÇA, J.B. de,; BACCIEGGA, I.F.; HABEKOST, C.R.; CRUZ, W.B. da, 1973. Geologia da Bacia Jaibaras; Ceará, Piauí e Maranhão. Projeto Jaibaras. DNPM/CPRM. Recife. Relatório final (5 vol).

COSTA, W. D. 1963. Contribuição ao estudo geológico da Bacia de Jaibaras. Arquivos de Geologia. Universidade do Recife. 4: 65-89.

CRANDALL, R. 1910. Geographia, Geologia, Supprimento d'Água, Transportes e Açudagem nos Estados Orientais do Norte do Brazil. Ceará, Rio Grande do Norte, ParahybaMinistério da Viação e Obras Públicas. Inspeciona de Obras Contra as Secas. Série I, D.H. Hydrologia, geologia, assumptos gerais. Rio de Janeiro. 131 p. (Publicação 4).

DANNI, J. C. M. 1972. Geologia da porção sul do Grupo Jaibaras - Ceará Rev. Bras. Geoc. 2 (2): 85-97.

DANTAS, J.R.A. 1974. Carta geológica do Brasil ao milionésimo: folhas Jaguaribe (SB.24) e Fortaleza (SA.24). MME/DNPM. Brasília. 95 p.

FERREIRA, E. 0.1972. Carta Tectônica do Brasil.Notícia explicativa. DNPM.Bol. 1. 19 p.

FETTER, A.M; SANTOS, T.J.S.dos; NOGUEIRA NETO, J.A., SCHMUS, W.R.V. 1995. Geocronologia U/Pb em zircão e $\mathrm{Sm} / \mathrm{Nd}$ em rocha total do estado do Ceará-Resultados iniciais. In: Simp. Geol. do Nordeste. 16. Recife, 1995. Atas... Recife, Bol. Núcleo Nordeste da SBG. 14 (2), p. $418-422$

GAMA Jr.,T. 1992. Geologia do Setor Nordeste da Zona de Cisalhamento de Granja - Noroeste do Ceará. Tese de Doutorado apresentada ao CG-UFPa. Belém. 109p.

GAMA JÚNIOR, T.;COSTA, J. B. da S. HASUI, Y.; OLIVEIRA, M. A. F. 1990. A zona de cisalhamento de Granja e seu significado tectônico. In: Cong. Bras. Geol. 36. Natal, 1990. Anais... Natal, SBG. v. 5, p. 2330-2339.

GAUDETTE, H. E.; ABREU, F. de A. M. de,; LAFON, J. M.; GORAYEB, P. S. de S. 1993. Evolução transamazônica do cinturão de cisalhamento noroeste do ceará: Novas evidências geocronológicas. In: Simp. Geol do Nordeste. 15. Natal, 1993. Atas... Natal, Bol. Núcleo Nordeste da SBG. v. 13. p. 317-319.
GORAYEB, P, S. de S. ; ABREU, F. de A. M. de ; CORRÊA, J. A. M. ; MOURA, C. A. V. 1988. Relações estratigráficas entre o granito Meruoca e a seqüência Ubajara-Jaibaras. In: Congr. Bras. de Geol. 7. Belém, 1988. Anais... Belém, SBG. v. 6. p. 2678-2688.

HACKSPACHER, P.C.; SOARES, J.W.; PETTA, P.A. 1988. A geologia do Grupo Ubajara - Região de Frecheirinha. In: Cong. Bras. Geol., 35. Belém, Anais... Belém, v. 6. p. 2661-2677.

JARDIM de SÁ, E.F. 1994. A evolução proterozóica da Província Borborema. In: Simp. Geol. do Nordeste. 11. Natal, 1994. Atas... Naral, Boi. Núcleo Nordeste da SBG. 9 : 297-316.

JARDIM DE SÁ, E. F.; HACKSPACHER, P. C.; NOGUEIRA, A. B. M.; LINS, F. A. ; McREATH, I. ; SRIVASTAVA, N. K. 1979 Observações sobre a estratigrafia e seqüências ígneas da Bacia Jaibaras, Noroeste do Ceará. In: Simp. Geol. Nordeste. 9. Natal, 1979. Atas... Natal, Bol. Soc. Bras. Geol. Núcleo Nordeste, v. 7. p. 30-38.

KEGEL, W. 1956. As inconformidades na Bacia do Parnaíba e zonas adjacentes. DNPM / DGM . Rio de Janeiro. 59 p. (Boletim 160).

KEGEL, W. 1965. A estrutura geológica do Nordeste do Brasil. DNPM/DGM. Rio de Janeiro. 47 p. (Boletim 227).

KEGEL, W.; SCORZA, E.P.; COELHO, F.C.P. 1958. Estudos geológicos no Norte do Ceará. DNPM/DGM. Rio de Janeiro. 46 p. (Boletim 184).

KORPERSHOEK, H.R.; MENDONÇA, J.A.C. ; TORQUATO, J.R. 1979 A geologia da região de Pedra Verde (Ceará). In: Simp. Geol. Nordeste, 9. Natal, 1979, Atas... Natal, SBG. Núcleo Nordeste, p. 349-363. (Boletim 7)

MABESOONE, J. M. ; BEURLEN, K. ; RAND, H. M. 1971. Geologia da Bacia de Jaibaras (Ceará). Universidade Federal de Pernambuco, Instituto de Geociências. Série B: Estudos e Pesquisas, 2 :1-116.

MELLO, A. A. de; SOUZA, E. M. de , ; MENDONÇA, J. C. G. 1978. A tectônica linear do Estado do Ceará. In: Cong. Bras. Geol., 30. Recife, 1978. Anais... Recife, SBG. v.1. p. 393-406.

MORAES, L.J. 1924. Serras e Montanhas do Nordeste. Publ.58, Série I,D, IFOCS., 2 vol., Rio de Janeiro.

NASCIMENTO, D. A. do, \& GAVA, A. 1979. Novas considerações sobre a estratigrafia da Bacia Jaibaras. In: Simp. Geol. Nordeste. 9. Natal, 1979. Atas... Natal, Boi. Soe. Brás. Geol. Núcleo Nordeste, v. 7. p. 14-29.

NASCIMENTO, D.A. do,; GAVA, A.; PIRES, J. de,; TEIXEIRA, W. 1981. Geologia da folha $S A .24$ - Fortaleza. In: Projeto Rabambrasil. Rio de Janeiro. DNPM. $21: 23-212$.

NOGUEIRA NETO, J. de A.; TORQUATO, J.R.F.; ARTHAUD, M.H.; MACAMBIRA, M.J.B. 1989. Reavaliação e novos dados geocronológicos do Maciço Mediano de Granja (CE). In: Simp. Geol. Nordeste. 13. Fortaleza,1989. Atas... Fortaleza, Boi. Soe. Brás. Geol. Núcleo Nordeste, v. 11. p. 181-183.

NOVAIS, F. R. G.; BRITO NEVES, B. B. de, ; KAWASHITA, K. 1979. Reconhecimento cronoestratigráfico da região noroeste do Ceará. In: Simp. Geol. Nordeste. 9. Natal, 1979. Atas... Fortaleza, Bol. Soc. Bras. Geol. Núcleo Nordeste, v. 7. p. 93-110.

OLIVEIRA, A I. de, \& LEONARDOS, O H. 1940. Geologia do Brasil.Ed. Comemorativa dos Centenários de Portugal. Congresso Científico de Lisboa. $2^{\circ}$ Ed. (1943) Rio de Janeiro, Ministério da Agricultura. 813 p.

OLIVEIRA, D.C. -1987- Contribuição ao estudo da geologia do noroeste do Ceará. Mapeamento geológico de uma área ao sul de Granja. Relatório de graduação. UFRN. Mimeografado. 232 p.

OLIVEIRA, D.C. 1992. Geologia do Graben Martinópole, área de Campanário / Paula Pessoa (Granja-CE). Implicações na evolução litoestratigráfica e tectonomagmática do noroeste do Ceará. Rev. Bras. Geoc. 22 (2): 143-156.

PRADO, F. da S.; MENDONÇA, J.C.G. da S.; MORAES, J.B.A. de; MEDEIROS, M. de F.; ASSUNÇÃO, P.R.S. de; ANDRADE, V.A. MEDEIROS, R.P. de, 1979. Projeto Martinópole. DNPM/CPRM Relatório final. 5 Vol. (editado em 1981).

SAADI, A. \& TORQUATO, J. R. 1992. Contribuição à neotectônica do estado do Ceará. Rev. de Geologia. 5 : 5-38.

SANTOS, T.J.S. dos, 1993. Aspectos geológicos de uma área a sudoeste de Granja. Região noroeste do Ceará. Tese de Mestrado apresentada ao IGCE/UNESP. Rio Claro. $159 \mathrm{p}$.

SANTOS, T.J. dos \& HACKSPACHER, P.C. 1992. Geologia do Grupo Martinópole, noroeste do Ceará. In: Cong. Bras. Geol., 37. São Paulo, 1992. Anais... São Paulo, SBG. v.1. p. 298-299.

SILVA FILHO, M. A. da, 1995. A província Borborema: Uma nova abordagem geotectônica. In: Simp. Geol. do Nordeste. 16. Recife, 1995. Ato... Recife, Bol. Núcleo Nordeste da SBG. 14 (2), p.384-390.

SMALL, H. L. 1914. Geologia e Supprimento d 'Água subterrânea no Piauhy e parte do Ceará. Ministério da Viação e Obras Públicas. Inspeciona de Obras Contra as Secas. Série I.D. Geologia. Rio de Janeiro. 169 p. (Publicação 32). 
TORQUATO, J.R. 1995. A geologia do noroeste do Ceará. Uma visão histórica. Rev. Geol. 8 : 5-170.

TORQUATO, J.R. \& PEDREIRA, L.H.S.T. 1994. Considerações sobre a geologia da região de Granja-Martinópole (CE). In: Cong. Bras. Geol., 38. Camboriú, 1994. Anais... Camboriú, SBG. p. 239-240.

TORQUATO, J.R.; PEDREIRA, L.H.S.T. ; NOGUEIRA NETO, J.de A. 1987. Projeto Granja-Geologia local. CNPq, Relatório final, Processo 408206/84-GL. Mimeografado. $81 \mathrm{p}$.

VAUCHEZ, A.; NEVES, S.; CABY, R.; CORSINI, M.; EGYDIO-SILVA, M.; ARTHAUD, M.; AMARO.V. 1995. The Borborema shear zone system, NE Brazil. Journal of South American Earth Sciences. 8 : 247-266.
WILLIAMS, H.E. 1926. Notas sobre a geologia e Recursos minerais do Norte do Ceará. Ser. Geol. Min. Brasil. Bol. Série Geol Mineral. Rio de Janeiro, p. 1-42. (Boletim 16).

WINGE, H. 1967. Breves notas sobre a geologia do Nordeste do Ceará. Ministério do Interior. SUDENE. Divisão de Geologia. Bol. de Estudos. 3: 13-18.

Manuscrito A921

Recebido em 01 de junho de 1997

Revisão dos autores em 28 de junho de 1997 Revisão aceita em 30 de junho de 1997 